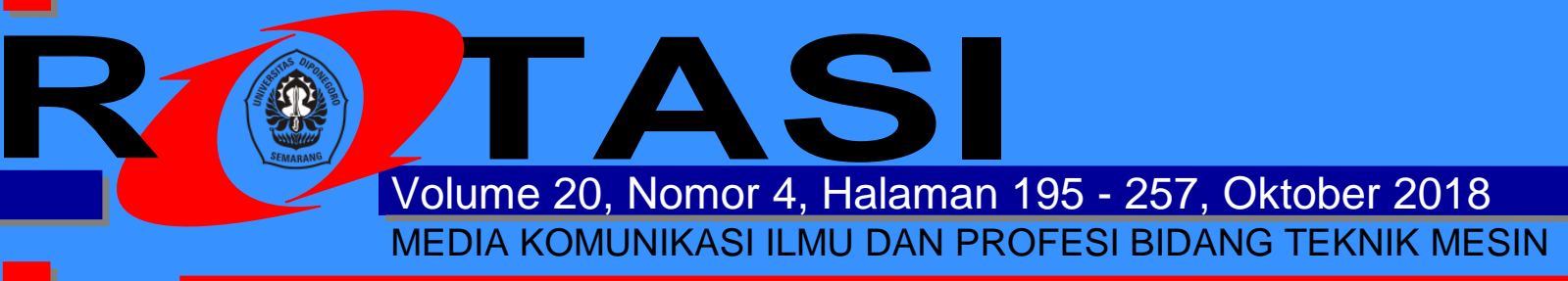

(R) Peningkatan Nilai Kekerasan pada Bucket Teeth Excavator dengan Metode Pack Carburizing dan Media Quenching Oli SAE 20W-50 Serta Cangkang Kerang sebagai Energizer

(Athanasius Priharyoto Bayuseno, Dipo Adi Negoro)

(R) Pengaruh Jarak Penembakan pada Pelapisan 95MXC Terhadap Sifat Kekerasan dan Keausan Material SS 304 dengan metode Twin Wire Arc Spray (TWAS)

(Deni Fajar Fitriyana, Gunawan Dwi Haryadi, Sulardjaka, Norman Iskandar, Abdi Gilang Amrizal)

(Riagnosis Kerusakan Roda Gigi dengan Metode Ensemble Emperical Mode Decomposition (EEMD)

(Eky Fortuna Pradika, Achmad Widodo, Ismoyo Haryanto)

(R) Kinerja Sistem Kotak Pendingin Peltier Tenaga Surya Untuk Penyimpanan Sayur dan Buah

(Terang UHS Ginting Manik, Tulus Burhanuddin Sitorus, Ferry Sembiring)

(R) Analisa Parameter Hidrodinamika Remotely Operated Vehicle (ROV) Kelas Obervasi

(Dhimas Satria, Romi Wiryadinata, Ni Ketut Caturwati, Haryadi, Imron Rosyadi)

(R) Analisis Metode Elemen Hingga Artificial Hip Joint Saat Gerakan Salat

(Aditya Candratama, Yogi Prasetyo, Jamari, Rifky Ismail, Ismoyo Haryanto)

(R) Analisis Displacement dan Tegangan von Mises Terhadap Chassis Mobil Listrik Gentayu

(Rifky Ismail, Munadi, Zakki Kurniawan Ahmad, Athanasius Priharyoto Bayuseno)

(R) Analisis Distribusi Temperatur dan Aliran Fluida pada Proses Pengeringan Butiran Teh Bentuk Silinder Di Dalam Fluidized Bed Dryer Menggunakan Computational Fluid Dynamic (CFD)

(MSK Tony Suryo Utomo, Eflita Yohana, Mauli Astuti Khoiriyah)

(R) Dampak Proses Sintering Material Keramik pada Sifat Mekanik dan Dimensi Suatu Produk

(Sulistyo)

(R) Application of polishing AISI 316L stainless steel ball bearing with a magnetic abrasive finishing process: a review

(Patrick Munyensanga, P. Paryanto, Moh Nor Ali Aziz) 


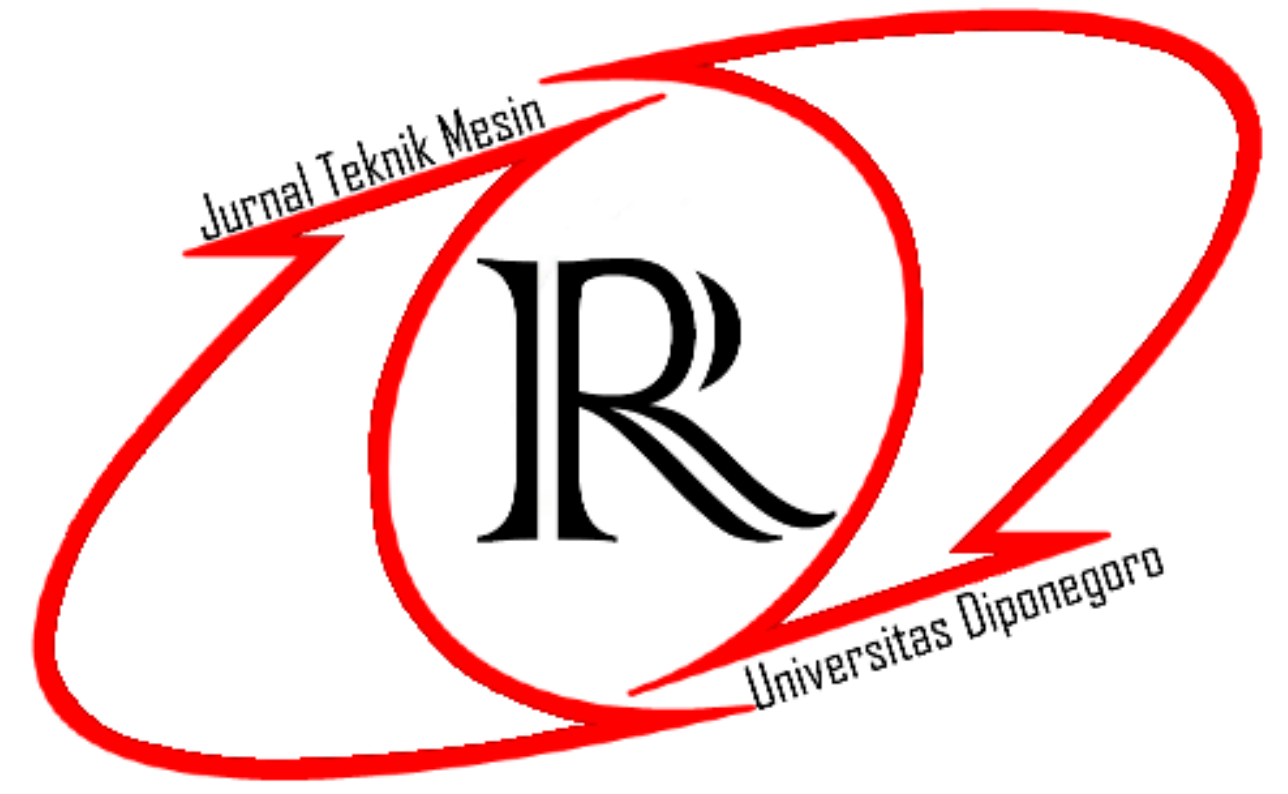




\section{FOKUS DAN RUANG LINGKUP JURNAL ROTASI}

Jurnal ROTASI (p-ISSN: 1411-027X; e-ISSN: 2406-9620; adalah peer-reviewed journal yang mempublikasikan artikel-artikel ilmiah dari disiplin ilmu Teknik Mesin. Berbagai topik dalam ilmu Teknik mesin dapat diterima di jurnal ini, meliputi:

- Bidang Efisiensi dan Konversi Energi

- Bidang Material Teknik

- Bidang Perancangan Teknik

- Bidang Sistem Kontrol dan Robotika

- Bidang Getaran dan Diagnosa Mesin

- Bidang Termofluida

- Bidang Proses Produksi

- Bidang Tribologi

- Bidang CNC/CAD/CAM

Artikel-artikel yang dipublikasikan di jurnal Rotasi meliputi hasil-hasil penelitian ilmiah asli (prioritas utama), artikel ulasan ilmiah yang bersifat baru (tidak prioritas), atau komentar atau kritik terhadap tulisan yang ada di Rotasi. Rotasi menerima manuskrip atau artikel dalam bidang teknik mesin dari berbagai kalangan akademisi dan peneliti baik nasional maupun internasional.

Artikel-artikel yang dimuat di jurnal Rotasi adalah artikel yang telah melalui proses penelaahan oleh Mitra Bebestari (peer-reviewers). Mulai tahun 2015, jurnal Rotasi hanya menerima artikel-artikel yang berasal dari hasil-hasil penelitian asli (prioritas utama), dan artikel ulasan ilmiah yang bersifat baru (tidak prioritas). Keputusan diterima atau tidaknya suatu artikel ilmiah di jurnal ini menjadi hak dari Dewan Penyunting berdasarkan atas rekomendasi dari Mitra Bebestari. 


\title{
TIM EDITOR
}

\author{
Ketua Penyunting (Editor in Chief): \\ Ir. Eflita Yohana, MT, Ph.D
}

Penyunting Ahli (Associate Editor):

Dr. Mohammad Tauviqirrahman, ST, MT

Dewan Penyunting (Editorial Board):

Dr. Ir. Nazaruddin Sinaga, MS (Departemen Teknik Mesin Universitas Diponegoro)

Dr. Dipl.-Ing. Ir. Berkah Fajar Tamtomo K. (Departemen Teknik Mesin Universitas Diponegoro)

Dr. Eng. Gunawan Dwi Haryadi, ST, MT (Departemen Teknik Mesin Universitas Diponegoro)

Dr.Ing. Ir. Ismoyo Haryanto, MT (Departemen Teknik Mesin Universitas Diponegoro)

Joga Dharma Setiawan, BSc, MSc, Ph.D (Departemen Teknik Mesin Universitas Diponegoro)

MSK. Tony Suryo Utomo, ST, MT, Ph.D (Departemen Teknik Mesin Universitas Diponegoro)

Dr. Eng. Dedi Suryadi, ST, MT (Departemen Teknik Mesin Universitas Bengkulu)

Dr. Eng. Syamsul Hadi, ST, MT (Jurusan Teknik Mesin Universitas Sebelas Maret)

Dr. Rifky Ismail, ST, MT (Departemen Teknik Mesin Universitas Diponegoro)

Rusnaldy, ST, MT, Ph.D (Departemen Teknik Mesin Universitas Diponegoro)

Sri Nugroho, ST, MT, Ph.D (Departemen Teknik Mesin Universitas Diponegoro)

Dr. Susilo Adi Widyanto, ST, MT (Departemen Teknik Mesin Universitas Diponegoro)

Syaiful, ST, MT, Ph.D (Departemen Teknik Mesin Universitas Diponegoro)

Dr. Ir. Toni Prahasto, MSc (Departemen Teknik Mesin Universitas Diponegoro)

\section{Staff editorial Office:}

Eko Saputra, ST, MT, Nita Kurniawati, AMd, dan Dr. Eng. Munadi, ST, MT

Penerbit: Departemen Teknik Mesin, Fakultas Teknik, Universitas Diponegoro

\section{Sekretariat Editorial Office:}

Departemen Teknik Mesin, Fakultas Teknik, Universitas Diponegoro

J1. Prof.H.Soedarto, SH, Kampus UNDIP Tembalang, Semarang. Telp. (024)7460059

Facsimile: (024)7460059 ext.102

Website: http://ejournal.undip.ac.id/index.php/rotasi; E-mail: rotasi@undip.ac.id 


\section{KATA PENGANTAR}

Jurnal ROTASI Volume 20 Nomor 4 bulan Oktober tahun 2018 merupakan edisi ketiga untuk penerbitan tahun 2018. Artikel-artikel yang diterbitkan oleh jurnal Rotasi telah dipublikasi secara Fulltext dan Open Access dalam format PDF secara online di: http://ejournal.undip.ac.id/ index.php/rotasi. Jurnal ROTASI hanya memuat artikel-artikel yang berasal dari hasil-hasil penelitian saja dan setelah ditelaah para Mitra Bebestari.

Artikel-artikel yang termuat dalam jurnal Rotasi ini adalah artikel-artikel yang sudah melalui proses penilaian atau review oleh Mitra Bebestari dan/atau Dewan Penyunting. Penulis harus memperhatikan kualitas isi artikel sesuai petunjuk penulisan artikel dan komentar dari Mitra Bebestari yang ditampilkan di masing-masing penerbitan atau dapat didownload di website jurnal tersebut. Jumlah artikel yang terbit pada nomor ini sebanyak lima judul artikel.

Dewan Penyunting akan berusaha terus meningkatkan mutu jurnal sehingga dapat menjadi salah satu acuan yang cukup penting dalam perkembangan ilmu Teknik Mesin. Penghargaan dan terima kasih yang sebesar-besarnya kepada Mitra Bebestari bersama para anggota Dewan Penyunting dan seluruh pihak yang terlibat dalam penerbitan jurnal ini.

Dewan Penyunting juga mengharapkan artikel ilmiah dari para pembaca untuk dapat diterbitkan pada Volume 21 Nomor 1 bulan Januari tahun 2019 setelah melalui proses telaah oleh Dewan Penyunting dan/atau Mitra Bebestari. Petunjuk penulisan lengkap untuk tahun 2019 ditampilkan di portal jurnal ini.

Salam,

Ketua Penyunting 


\section{DAFTAR ISI}

FOKUS DAN RUANG LINGKUP

TIM EDITOR

iii

KATA PENGANTAR

DAFTAR ISI

Peningkatan Nilai Kekerasan pada Bucket Teeth Excavator dengan Metode Pack Carburizing dan Media Quenching Oli SAE 20W-50 Serta Cangkang Kerang sebagai Energizer

(Athanasius Priharyoto Bayuseno, Dipo Adi Negoro)

Pengaruh Jarak Penembakan pada Pelapisan 95MXC Terhadap Sifat Kekerasan dan Keausan Material SS 304 dengan metode Twin Wire Arc Spray (TWAS)

(Deni Fajar Fitriyana, Gunawan Dwi Haryadi, Sulardjaka, Norman Iskandar, Abdi Gilang Amrizal)

Diagnosis Kerusakan Roda Gigi dengan Metode Ensemble Emperical Mode Decomposition (EEMD)

(Eky Fortuna Pradika, Achmad Widodo, Ismoyo Haryanto)

Kinerja Sistem Kotak Pendingin Peltier Tenaga Surya Untuk Penyimpanan Sayur dan Buah

(Terang UHS Ginting Manik, Tulus Burhanuddin Sitorus, Ferry Sembiring)

Analisa Parameter Hidrodinamika Remotely Operated Vehicle (ROV) Kelas Obervasi (Dhimas Satria, Romi Wiryadinata, Ni Ketut Caturwati, Haryadi, Imron Rosyadi)

$195-201$

Analisis Metode Elemen Hingga Artificial Hip Joint Saat Gerakan Salat

(Aditya Candratama, Yogi Prasetyo, Jamari, Rifky Ismail, Ismoyo Haryanto)

Analisis Displacement dan Tegangan von Mises Terhadap Chassis Mobil Listrik Gentayu (Rifky Ismail, Munadi, Zakki Kurniawan Ahmad, Athanasius Priharyoto Bayuseno)

Analisis Distribusi Temperatur dan Aliran Fluida pada Proses Pengeringan Butiran Teh Bentuk Silinder Di Dalam Fluidized Bed Dryer Menggunakan Computational Fluid Dynamic (CFD)

(MSK Tony Suryo Utomo, Eflita Yohana, Mauli Astuti Khoiriyah)

Dampak Proses Sintering Material Keramik pada Sifat Mekanik dan Dimensi Suatu Produk

(Sulistyo)

Application of polishing AISI 316L stainless steel ball bearing with a magnetic abrasive finishing process: a review

(Patrick Munyensanga, P. Paryanto, Moh Nor Ali Aziz)

UCAPAN TERIMA KASIH KEPADA PARA REVIEWER PADA TERBITAN INI

App.1

PETUNJUK PENULISAN 2018 (AUTHOR GUIDELINES 2018)

App.2-4 